\title{
COMPETENCES OF THE ADMINISTRATOR'S GRADUATE PROFILE IN A GLOBAL CONTEXT, A REVIEW OF THE LITERATURE
}

\section{COMPETENCIAS DEL PERFIL DE EGRESO DEL ADMINISTRADOR EN UN CONTEXTO GLOBAL, UNA REVISIÓN DE LA LITERATURA}

Reception: 2019-06-12 - Acceptance: 2020-03-15

\section{Carlos Francisco José Tassara Salviati ${ }^{i ; a}$}

(iD) ORCID iD 0000-0001-6227-5243

1 Ricardo Palma University. Faculty of Economic and Business Sciences. Global Business Administration School.

a Master of Business Administration.

\begin{abstract}
In an increasingly integrated and challenging world, companies require administrators who are able to cope with a globalized and highly competitive business environment. In that sense, the objective of the research is to establish the competences of the administrator's graduate profile to perform in a global context. To this aim, a qualitative design research of documentary type was developed, using as a source of information scientific papers indexed in the Google Academic database. An important finding is that generic competences such as teamwork, strategic leadership, adaptation to change, technology management and ability to interact in multicultural environments, among others, are more valued by employers than specific competences.
\end{abstract}

Keywords: Competences; Administration; Globalization.

\section{RESUMEN}

En el marco de un mundo cada vez más integrado y de grandes desafíos, las empresas requieren de administradores que sean capaces de hacer frente a un entorno empresarial globalizado y altamente competitivo. En ese sentido, el objetivo de la investigación es establecer las competencias del perfil de egreso del administrador para desempeñarse en un contexto global. Para ello se desarrolló una investigación de diseño cualitativo de tipo documental, utilizando como fuente de información artículos científicos indexados en la base de datos Google Académico. Un hallazgo importante es que las competencias genéricas como trabajo en equipo, liderazgo estratégico, adaptación al cambio, manejo de la tecnología y habilidad de interacción en entornos multiculturales, entre otras, son más valoradas por los empleadores que las competencias específicas.

Palabras clave: Competencias; Administración; Globalización. 


\section{INTRODUCTION}

Nowadays, the dynamism of organizations is marked by globalization and the constant changes it generates. Therefore, administration professionals must be prepared to face these challenges (Agudelo, Bedoya, Arteaga, Cardona and Bustamante, 2017).

In that sense, ManpowerGroup (2018), conducted a study with 39,195 employers in 43 countries around the world, detecting that companies in various economic sectors, present serious difficulties to fill the jobs they have available. According to this study, $43 \%$ of those who were interviewed indicated that they cannot find employees with the right combination of technical and human skills they need, being this situation more pronounced in organizations with more than 250 workers. In addition, it is pointed out that the strengthening of the global economy has increased the demand for hiring personnel; however, the shortage of talent has been increasing in recent years.

In this regard, it is the role of universities to evaluate the needs of the labor market continuously and align them with the competences of the graduate profile of the professional careers they offer, in order to generate an approach between the labor and educational environments, adapting the competences of their graduates to the changes in the profession they will perform (Richart, Álvarez y Martínez, 2019).

Taking into account the information above mentioned, this research is guided by the following question: Which are the competences of the administrator's graduate profile in a global context?

For this reason, the purpose of the paper is to establish the competences of the administrator's graduate profile in a global context. To this aim, it is explained initially what a graduate profile by competences in a university field implies, to then to point out the challenges of administrators dealing with globalization, and finally, based on the review of scientific papers consulted in the Google Academic database, to establish the most relevant competences to be considered in the professional education of an administrator who works in a globalized scenario in order to draw conclusions about them.

\section{MATERIAL AND METHODS}

The research followed a qualitative design of documentary type, based on the review of indexed scientific papers published in the period 2015 - 2019 in the academic Google database, selecting those documents whose content was linked to topics such as: Competences of the administrator's profile, characterization of the administrator's profile, management skills in a global environment, administration in the 21st century.

Later on, each paper was reviewed and a matrix was developed that helped to organize the information, allowing firstly, to relate each author with their respective contributions, and then to identify in a systemic way the common aspects and thus establish the generic and specific competences required by the administrator in a globalized environment.

\section{RESULTS}

\section{Graduate profile by competences in the university field}

In recent years the culture of quality and continuous improvement has been accentuated in all kind of organizations around the world. This approach, which is centered on the client, seeks to adapt permanently the business processes to the changes and new demands of its consumers (Lizarzaburu, 2015).

In this context, higher education institutions have not been immune to these approaches, since they have to deal with accreditation processes at an international as well as national level, which together seek to ensure that universities improve their academic and administrative processes continually, ensuring that the programs they offer were required by the productive sector and that their graduates, were prepared to deal with the demands of the work environment they will face (Superintendencia Nacional de Educación Superior Universitaria [SUNEDU], 2019). 
In that sense, the World Declaration on Higher Education in the 21st Century: Vision and Action, issued by the United Nations Educational, Scientific and Cultural Organization [UNESCO] (1998), proposes a student-centered educational model, pointing out the importance to evaluate the content, methodologies applied and other aspects of the curriculum systematically, in order to ensure that teaching is in line with the new technologies and practices of the modern world.

Within this analysis, the graduate profile is a key element for the improvement of the curriculum, since it explicitly details the set of skills that the graduate must possess at the end of his or her training process. Likewise, the graduate profile represents the commitment that the university assumes with its students and that is where the importance of its continuous revision and updating lies, through the interaction among the university, the business sector and those who work in the profession (Pontificia Universidad Católica del Perú - Dirección de Asuntos Académicos [PUCP-DAA], 2012).

In this regard, the Tuning Project - Latin America (2007), which is based in Europe as an effort to reflect on higher education, conducted a study to identify and exchange information on competences, teaching-learning approaches, credits and quality processes in 19 countries and 190 Latin American universities, where it is emphasized that the graduate profile is composed of a list of competences that can be carried out at the end of the educational process, understanding that a competence is the ability of the human being to effectively and autonomously solve the situations that arise in life (in this case in the work context), which includes the cognitive capacity (knowledge), the sensory-motor capacity (skills) and the attitudes and values with which the activity is developed.

Likewise, according to the Tuning Project - Latin America (2007), the competences can be classified into generic and specific. Generic or transversal competences are common to different areas of study and are linked to the capacity to learn, think and make decisions, to act guided by social values, technological and intercultural communication capacity, and interpersonal skills among the most important ones. On the other hand, specific competences are directly related to a certain field of study for the performance of a profession.

\section{Challenges for administrators in the face of globalization}

According to Koontz, Weihrich and Cannice (2012), to administrate is one of the most important activities, as it involves coordinating individual efforts to achieve group goals. They also point out that as human organizations have grown significantly and become more complex, the work of the administrator becomes even more important.

In addition, Robbins and Coultier (2014) add that administration is focused on ensuring that the organization's activities are carried out with efficiency and efficacy. In this sense, they refer to the fact that the administrator must seek to optimize the use of resources (efficiency) and achieve the proposed objectives at the right time (efficacy).

Jácome, Tinajero, and Suárez (2018) tell us that the speed at which changes occur makes it necessary for organizations, in the eagerness to achieve their objectives, to became in adaptable and flexible entities in the face of the new circumstances that surround them. In this regard, Koontz, Weihrich and Cannice (2012), state that one of the most relevant factors of change is the phenomenon of globalization, which from the perspective of Peng (2018), implies close integration between countries and people around the world. In this regard, Cerbone and Rosales (2019) mention that the signing of free trade agreements between countries and the creation of economic blocks generate new forms of commercialization and the development of more demanding and larger markets.

In view of this panorama, Jácome et al. (2018) mention that the administrator who acts in a global scenario, performs in organizations that operate in different countries, interacting with employees, customers and suppliers belonging to diverse cultures, where the handling of information, technology and innovation processes are fundamental for the survival of the company.

\section{Competences of the administrator's graduate profile in a global context}

After reviewing the literature regarding the competences of the administrator's graduate profile in a global context, several contributions were found that were organized according to author and year of publication, which are shown in table 1. 
Table 1

Competences of the administrator's graduate profile in a global context according to author and year of publication.

Author(s) and year

of publication

Cascio y Boudreau Social intelligence, adaptive thinking, intercultural competence, computer skills and (2015) data-based reasoning, new media management, transdisciplinary understanding and integration, analysis of the external environment, knowledge management and virtual collaboration.

Moreno, Castrillón, General competences: Ethical commitment, commitment to quality, teamwork, mastery Sánchez y Moreno and effectiveness in applying knowledge in the field and assertiveness in the decision(2016) making process.

Specific competences: Leadership for the achievement of goals in the organization; managing human, physical, financial and other resources of the organization; making decisions on investment, financing and management of financial resources in the company; developing strategic, tactical and operational planning; and interpreting accounting and financial information for management decision making.

Agudelo et al. Teamwork, assertive communication, leadership, management of informatics tools, analysis (2017)

Chan y Canul (2017)

Vallejos, Beltrán y

Cervantes (2017)

Jácome et al. (2018) Flexible to the challenges of globalization and technological advances, management of integral processes of a company that leaves its national market to embrace the world market.

De Aguilera, Good work habits, honesty, punctuality, productivity, fellowship and teamwork.

Cancelo y Barquero

(2018)

Blanco, Cruz,

Romo, y Tejeda

(2018)

Kuzin (2018)

Cultural competences, such as global knowledge of other cultures, ability to speak other languages, attitudes of adaptability and the experience of dealing with different multicultural environments, make the internationalization of companies easier.

Global competence: Ability to explore local and global intercultural aspects to understand and appreciate the perspectives and worldviews of others in order to establish appropriate and effective interactions with different cultures, acting for collective well-being and sustainable development. It involves four components: Understanding of the international context, comfort with dissonance, multicultural leadership and behaviour, and capacity for interaction in digital media.

Richart et al. (2019) Decision-making skills, new business strategies, leadership, problem-solving skills and teamwork.

Cerbone y Rosales Ability to interact with other people who are part of the organization, possess skills that (2019) allow them to properly manage internal and external relations that provide a good working environment.

Patiño y Valencia Technological and innovative profile, linked to the monitoring of the environment, the (2019) strategic integration of technology to routine activities and in processes of marketing and technological exchange, knowledge management and innovation of new products and services.

From the analysis of the above-mentioned contributions, the main generic and specific competences of the administrator's graduate profile in a global context, that can be identified, are detailed in table 2 . 
Table 2

Competences of the administrator's graduate profile in a global context according to author and year of publication.

\begin{tabular}{lll}
\hline \multicolumn{1}{c}{ Generic competences } & \multicolumn{1}{c}{ Specific competences } \\
\hline - Teamwork, both face-to-face and virtual. & $\cdot$ Formulate strategic, tactical and operational plans. \\
- Strategic leadership. & - Human talent management. \\
- Adaptation to change. & - Finance management. \\
- Technology and database management & $\cdot$ Marketing and sales management. \\
- Monitoring of the external environment. & & \\
- Ethical behavior. & \\
\hline
\end{tabular}

\section{DISCUSSION}

In the review of the literature, it can be seen that most authors agree in highlighting the importance of generic or transversal competences. This idea is in line with that mentioned by Richart et al. (2019), who indicate that employers value this type of skills much more and even consider them more important than specific skills. Furthermore, it is related to Agudelo et al. (2017), who refer to the fact that today's companies require resolute and proactive professionals.

In that regard, the most relevant generic competences that have been identified are teamwork both in person and virtually, strategic leadership, adaptation to change, technology and database management, the ability to interact in multicultural environments, monitoring of the external environment and ethical and responsible behavior with society. In this sense, it is evident that strategic leadership, adaptation to change and value-based management are elements that significantly influence the good performance of an administrator and contribute to strengthening the organizational culture (Chan and Canul, 2017). In addition, considering the speed of technological change, the importance of developing a technological and innovative profile of the administrator is highlighted, making him or her capable of monitoring the environment and strategically integrating technology with the organization's processes (Patiño and Valencia, 2019).

It is also essential that the administrator, in a global context, (i) has the ability to be prepared to the international context; (ii) be able to deal with change; (iii) be able to lead and interact in multicultural environments; and, (iv) have the ability to use and interact with technology. (Kuzin, 2018)

With regard to specific competences, the study was able to find coincidences in aspects such as the ability to formulate strategic, tactical and operational plans, human talent management, finance management, marketing and sales management and knowledge management. These results are largely in line with the findings of the study conducted by the Tuning Project - Latin America (2007) for the business administration career, which, based on the opinion of graduates, employers and academics, identifies as the most important specific competences the development of strategic, tactical and operational plans and the interpretation of accounting and financial information for making financing and investment decisions and human talent management.

An aspect not considered in the results of the Tuning Project - Latin America (2007) and which is indispensable for the administrator in the global environment, is the knowledge and development of strategies that facilitate the entry and consolidation of products and services in the different world markets, with which the role of marketing and sales management become fundamental factors (Blanco et al., 2018).

In addition to the above, the capacity to knowledge management becomes vitally important in a global environment, due to the accelerated progress of science and technology, which is one of the main factors for the competitiveness of companies (Patiño and Valencia, 2019).

Therefore, it can be concluded that universities have a great responsibility to constantly review and update the competences of the graduate profile of the programmes they offer in order to link the labour demands of the market with professional education. These competences can be classified as generic or transversal to various 
programs or subjects and as specific competences that are focused on a particular discipline.

Furthermore, it is evident that globalization, being a phenomenon that generates the integration of people and countries in various aspects, has a significant impact on the labor environment and therefore on the professional education of the future administrator.

As a result, the documentary review shows a holistic and dynamic graduate profile with a diversity of generic and specific competences to be developed, both in knowledge, soft skills, technological capabilities, understanding of multiculturalism, adaptation to change and ethically guided action, which are necessary for the administrator to manage the processes of organizations that operate in a global market strategically. The need to continue studying this subject in depth is evident, opening up the possibility of new research on the subject.

\section{REFERENCES}

Agudelo, D., Bedoya, E., Arteaga, J., Cardona, J. B., \& Bustamante, J. H. (2017). Tendencias actuales en términos de educación de los Administradores de Empresas en la ciudad de Medellín - Modalidad Investigación. Revista CIES, 8(1), 111 - 126. Recuperado de: http://www.escolme.edu.co/revista/index.php/cies/article/view/115/111.

Blanco, M., Cruz, j., Romo, H., \& Tejeda, A. (2018). Internacionalización de las Empresas Mexicanas en el Sur de los Estados Unidos y sus competencias globales. Norteamérica, 13(2), 143-168. doi: 10.20999/nam.2018. b004.

Cascio, W., \& Boudreau, J. (2015). The search for global competence: From international HR to talent management. Journal of World Business, 51(1), 103-114. doi: 10.1016/j.jwb.2015.10.002.

Cerbone, P., \& Rosales, D. (2019). Habilidades del buen administrador: Un mapeo sistemático. Revista mktDescubre - ESPOCH FADE, 14, 79 - 89. Recuperado de: https://www.researchgate.net/publication/337913921.

Chan, M., \& Canul, D. (2017). Modelo de competencias del directivo estratégico en un entorno global. Revista Global de Negocios, 10(6), 53-63. Recuperado de: https://papers.ssrn.com/sol3/papers.cfm?abstract_id=3071242.

De Aguilera, M., Cancelo, M., \& Barquero, J. (2018). The European perspective of the labour market for graduates in business administration: The Spanish case. European Accounting and Management Review, 5(1), 47-68. Recuperado de: https://ssrn.com/abstract=3305108.

Jácome, I., Tinajero, M., \& Suárez, I. (2018). La nueva administración del siglo XXI. Polo de Conocimiento, 3(7), 612-625.doi: 10.23857/pc.v3i7.576.

Koontz, H., Weihrich, H., \& Cannice, M. (2012). Administración una perspectiva global y empresarial. México D.F.: McGraw-Hill.

Kuzin, D. (2018). Global competences and challenges for business educators. The Journal of Social Sciences Research, 1, 54-60. doi: 10.32861/jssr.spi1.54.60.

Lizarzaburu, E. (2015). La gestión de la calidad en Perú: un estudio de la norma ISO 9001, sus beneficios y los principales cambios en la versión 2015. Revista Universidad \& Empresa, 18(30), 33-54. doi: 10.12804/rev.univ. empresa.30.2016.02.

ManpowerGroup. (2018). Resolviendo la escasez de talento: Construir, adquirir, tomar prestado y tender puentes. Recuperado de: https://www.manpower.com.pe/mpintranet/publicaciones/5686-7070551448398.pdf.

Moreno, J., Castrillón, J., Sánchez, J., \& Moreno, A. (2016). Perfil del administrador: construcción a partir de la experiencia Tuning-Colombia. Económicas CUC, 37(2), 23-46. doi: 10.17981/econcuc.37.2.2016.02.

Patiño, O., \& Valencia, J. (2019). Tendencias curriculares en gestión tecnológica e innovación en programas. Revista Virtual Universidad Católica del Norte, (56), 16-30. Recuperado de: https://revistavirtual.ucn.edu.co/index. php/RevistaUCN/article/view/1035.

Peng, M. (2018). Negocios Globales. México, D.F.: Cengage Learning. 
Pontificia Universidad Católica del Perú - Dirección de Asuntos Academicos. (2012). Guía para la elaboración del perfil del egresado de pregrado. Recuperado de: http://cdn02.pucp.education/academico/2014/06/18142051/ Guia_perfil_egresados_alta_resolucion.pdf.

Proyecto Tuning - America Latina. (2007). Reflexiones y perspectivas de la educación superior en America Latina. Recuperado de: http://tuningacademy.org/wp-content/uploads/2014/02/TuningLAlll_Final-Report_SP.pdf.

Richart, R., Álvarez, E., \& Martínez, R. (2019). Competencias del perfil del administrador: Análisis comparativo en diferentes modalidades educativas. Perfiles Educativos, 41(164), 82-98.doi: 10.22201/iisue.24486167e.2019.164.59108.

Robbins, S., \& Coultier, M. (2014). Administración. México D.F.: Pearson.

SUNEDU. (2019). Informe bienal sobre la realidad universitaria peruana. Lima: SUNEDU. Recuperado de: https:// www.sunedu.gob.pe/informe-bienal-sobre-realidad-universitaria/.

UNESCO. (1998). Declaración Mundial sobre la Educación Superior en el Siglo XXI: Visión y Acción. Paris: UNESCO. Recuperado de: https://unesdoc.unesco.org/ark:/48223/pf0000116345_spa: UNESCO.

Vallejos, H., Beltrán, L., \& Cervantes, L. (2017). Caracterización del perfil profesional de la carrera de Administración de la Universidad Técnica del Norte. Revista Publicando, 4(10), 278-288. Recuperado de: https://revistapublicando.org/revista/index.php/crv/article/view/491.

E-mail: ctassara@urp.edu.pe 